\title{
Article
}

\section{Influence of Forestry on the Formation of National Park Policy in Japan}

\author{
Taiichi Ito*
}

\begin{abstract}
The national park system of Japan was the first to integrate regulatory land use zoning within scenic areas that encompass a diversity of landownership patterns. This was because zoning regulation was the only practical way to establish national parks in a country lacking public land. The most influential factors determining the park and its zoning boundaries were land ownership and the regulation of forest management of 1933 . 90\% of proposed park lands was forested and often used for forestry. The boundaries of parks were determined after consideration of landownership: Public forests were preferred, and the restrictions governing private forests were relaxed in the case of inclusion. As a result, only $13 \%$ of the park lands were private when the twelve original parks were designated by 1936. As the majority of public land was national forest, the national park system of Japan was based on these forests as cores. This was due to following reasons. First, the national park policy could coexist with forestry when economic pressure was low and harvesting was not mechanized. Second, promoters of national parks were associated with forestry education, and sustainable forestry was popular issue among them. Third, case-study models like the American parks and the domestic Forest Law suggested that management of forested areas in the parks could continue. Thus, forestry was the real force behind the national park policy in Japan. Before the Second World War, influence of forestry on the national park policy was acceptable. However, as economic demands on forests increased after the War, easily manipulated forest landscape guidelines and double agency management made the forest areas in the national parks vulnerable to economic demands and jeopardized national park management.
\end{abstract}

Keyword: national parks, national forests, zoning, landownership, forest landscape management

\section{INTRODUCTION}

Japan initiated its national park system in 1931 after studying other systems, mainly those of the United States. However, there are several fundamental distinctions in the Japanese system. The most often quoted distinction concerns the diversity of landownership. The National Parks of Japan are designated over scenic areas which include private lands, and land use zoning applies within the boundaries. Parks in the United States were mainly established on federal lands by reserving public domains. However, recently zoning regulations have become very popular all

* Institute of Agricultural and Forest Engineering, University of Tsukuba, 1-1-1 Tennodai, Tsukuba, Ibaraki 305 Japan over the world, a reflection that exclusive designation of national parks is almost impossible even in sparsely populated countries. Therefore, zoning regulation is becoming more and more common, and is used even by the United States in Greenline Parks. Among the many countries adopting regulatory zoning for national parks, Japan's approach can be distinguished by the strong influence of forestry in determining each park boundary and zone.

Japan's national parks often include forested areas with active timber operations. Forested areas cover $89 \%$ of park lands, and national forests occupy $59 \%$ of park lands. (SugIuRA 1971). The ratio of national forests gets higher in core areas such as Special Areas. The national forests are managed by the Forestry Agency in the Ministry of Agriculture, Forestry and Fishery, and national parks are under the responsibility of the Environment Agency in the Prime Minister's Office. Thus the same park land is often under 
the control of two agencies. This is a striking contrast to American parks, where scenic national forest areas were often transferred from the Forest Service to the Park Service to be included in the national park system.

This paper sheds light on these issues, recognizing forestry as a moving force behind Japan's zoning regulation and the importance of double agency management during the formation of the national parks policy in Japan. The early development of Japan's national park has been divided into the following four stages, with each slightly overlapping: petitions (1911-1920), survey (1921 - 1926), legislation (1927- 1931), and designation (1932 -1936). The influence of forestry on both national and private lands at each stage is discussed.

In regard to sources, the unpublished documents from Tsuyoshi Tamura Library in the Environment Agency were often consulted. Tamura is said to be the father of Japan's national parks, and his publications (TAMURA $1948,1951)$ are often quoted as almost an official national park history. However, this author tried to consult original sources as often as possible to avoid depending too much on the personal views shown in Tamura's books.

\section{THE FIRST STAGE: FLOODING PETITIONS TO ESTABLISH NATIONAL PARKS}

The first stage started in 1911 when two national park petitions and a proposal were submitted to the Imperial Diet. One was for the Nikko area, the others for the Mt. Fuji area. By the end of the park movement, the number of such petitions had amounted to almost two hundred (TAMURA 1927). The petitioners were strongly motivated by an expectation of economic benefits and nationalism. The superiority of the landscapes in Japan was often mentioned by the promoters. The landscapes were recognized as a resource which would attract foreign tourists. Thus, the monumentalism and nationalism stimulated by the sudden influx of Western culture played important roles in the inauguration of the park movement. The expectation of economic development by international tourism reflected the depressed economy of the time.

These motivations are common with those of the national park movement in the United States. The characteristics important in the development of American national parks, such as nationalism towards monumental landscapes and the land being regarded as worthless except for tourism(RUNTE 1979), were also important in the movement to establish national parks in Japan. However, none of the petitions were recognized seriously at this stage, and conflicts over the use of natural resources like forests, minerals and water were not obvious yet. Therefore, the relationship between forestry and the national park was not discussed in the Diet. This was partially because the Forest Law of 1907 already provided for twelve types of Protection Forests, including scenic protection. This regulation was effective in conserving private forests, as they occupied $20 \%$ of the Protection Forests. In addition, the Forestry Bureau started to designate Preservation Forests in national forests according to the notification by the director in 1915. These were designated on the basis of scientific and cultural importance. In 1919, the City Planning Law and the Historic Sites, Scenic Beauty and Natural Monument Preservation Law were passed, and had considerable influence over the later National Park Law. In short, landscapes in both private and national forests already had some protection when the national park movement was initiated.

\section{THE SECOND STAGE: FIELD SURVEY TO CHOOSE PROPOSED SITES}

TAMURA, who majored in forestry and landscape architecture at the Imperial University of Tokyo, began to play a vital role from this stage. In 1920 he was hired by the Sanitary Bureau in the Ministry of Home Affairs. The Bureau had experience of public park management since 1873 and had been interested in national park management since 1911. In 1921, he and his assistant launched a field survey to identify suitable national park areas. The survey was interrupted by TAMURA's year-long trip to United States and Europe. While he was abroad, the Great Earthquake of 1923 demolished Tokyo, and the survey was interrupted for several years even after his return. However, this delay allowed TAMURA to develop fully as a national park planner with experience abroad. A flood of papers were published after his return, and many of his ideas were reflected in the formation of the national parks in Japan.

By 1927, the survey was finished, and sixteen areas were identified as possible national parks. In 1930, the Sanitary Bureau published the survey result. The report consisted of a descriptive volume (THE SANITARY BUREAU 1930a) and maps (The Sanitary Bureau 1930b). The report identified only fourteen of the original sixteen areas. This was a result of combining three parks into one, the Nihon Alps. The names and boundaries of two national parks were changed in the first supplement (THE SANITARY BUREAU 1932a). Daisetsuzan was added as the 15th proposed site in the second supplement (THE SANITARY Bureau 1932b), after TAmura's visit to the Daisetsuzan area in June, 1931.

Five topics were discussed for each proposed area: 1. studied area, 2. suitable park boundary, 3. qualification such as natural features, 4 . current facilities and use, and 5. future development possibility. Landownership was discussed in detail in the park boundary section and the 
Table 1 Landownership of the Proposed National Park Areas (March 1930)

\begin{tabular}{|c|c|c|c|c|c|c|c|c|}
\hline Number & Park Name & $\begin{array}{c}\text { Park Area } \\
\text { (ha) }\end{array}$ & $\begin{array}{c}\text { Imperial } \\
\text { Lands (ha) }\end{array}$ & $\begin{array}{c}\text { National } \\
\text { Lands (ha) }\end{array}$ & $\begin{array}{c}\text { Public } \\
\text { Lands (ha) }\end{array}$ & $\begin{array}{l}\text { Religious } \\
\text { Lands (ha) }\end{array}$ & $\begin{array}{c}\text { Private } \\
\text { Lands (ha) }\end{array}$ & $\begin{array}{c}\text { Ratio of } \\
\text { Private } \\
\text { Lands }(\%)\end{array}$ \\
\hline 1 & Akan & 84,800 & 24,500 & 37,600 & 0 & 0 & 22,700 & 26.8 \\
\hline 2 & Noboribetsu & 6,500 & 0 & 5,400 & 0 & 0 & 1,100 & 16.9 \\
\hline 3 & Onuma & 19,400 & 0 & 9,200 & 0 & 0 & 9,500 & 49.0 \\
\hline 4 & Towada & 47,900 & 0 & 46,800 & 0 & 0 & 1,100 & 2.3 \\
\hline 5 & Bandai-Azuma & 66,300 & 0 & 36,300 & 21,400 & 0 & 8,600 & 13.0 \\
\hline 6 & Nikko & 83,900 & 11,900 & 33,000 & 500 & 3,800 & 34,700 & 41.4 \\
\hline 7 & Fuji & 87,600 & 25,700 & 2,900 & 41,400 & 300 & 17,300 & 19.7 \\
\hline 8 & Nihon Alps & 204,100 & 5,900 & 174,000 & 16,500 & 0 & 7,700 & 3.8 \\
\hline 9 & Odaigahara-Ominesan & 35,400 & 4,400 & 1,100 & 10,400 & 0 & 19,500 & 55.1 \\
\hline 10 & Daisen & 19,300 & 0 & 9,200 & 8,100 & 0 & 2,000 & 10.4 \\
\hline 11 & Yashima-Shodoshima & 1,300 & 0 & 530 & 200 & 70 & 500 & 38.5 \\
\hline 12 & Aso & 75,300 & 0 & 10,000 & 43,800 & 0 & 21,500 & 28.6 \\
\hline 13 & Unzen & 11,100 & 0 & 8,700 & 2,000 & 0 & 400 & 3.6 \\
\hline \multirow[t]{2}{*}{14} & Kirishima & 22,080 & 0 & 21,100 & 0 & 80 & 900 & 4.1 \\
\hline & Total & 764,980 & 72,400 & 395,830 & 144,300 & 4,250 & 147,500 & 19.3 \\
\hline
\end{tabular}

Source: The Sanitary Bureau 1930a

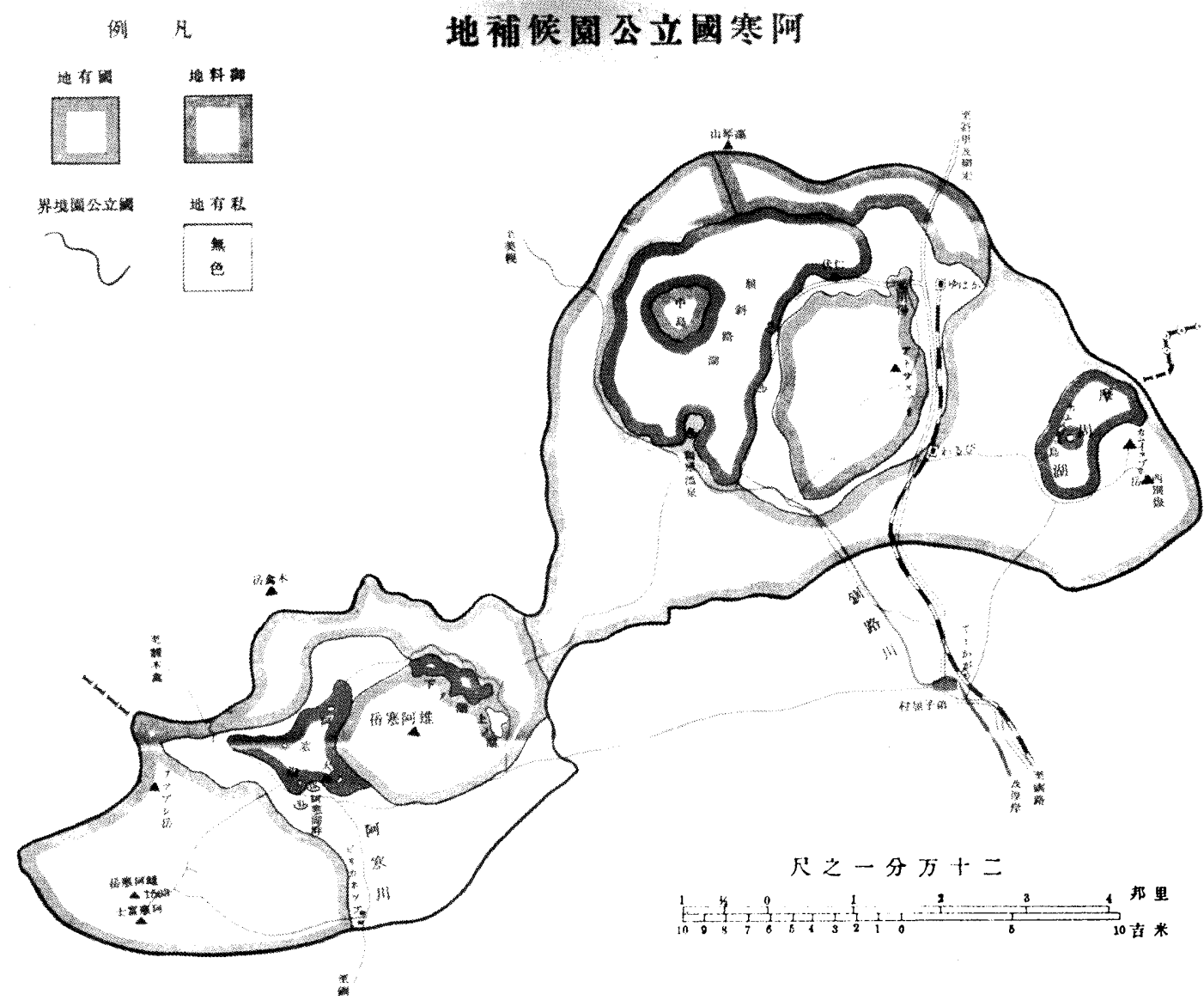

Fig. 1 Map of Proposed Akan National Park (the Sanitary Bureau 1930) 
attached table about the areas of the proposed parks . Ownership was divided into five categories; Imperial, national, public, religious and private (Table 1). Public lands are those owned by prefectures, cities, towns or villages. Religious lands are owned by Buddhist temples or Shinto shrines. The extent of religious land is a reflections that sublime mountains have been recognized as sacred monuments and protected for a long time in Japan.

On separate color maps of the proposed parks, landownership within the proposed boundary was divided into seven categories by separately identifying army-owned land from national land and prefectural land from public land, if applicable (Fig.1). These maps also contain information such as major routes and place names which are relevant to accessibility. However, the major objective of these maps was to show landownership clearly by colored boundary lines. Thus, TAMURA was well aware of the regulation problems related to private landownership. His response was to designate park areas in various public lands, especially national forests, and he tried to avoid private lands, to prevent land use conflicts.

TAmURA's visit to the United States in 1923 was commissioned by two agencies. The Forestry Bureau in the Ministry of Agriculture and Forestry commissioned Tamura to study forest recreation in U.S. national forests. The Ministry of the Home Affairs expected an investigation of the national parks. The report on forest recreation was published partially in 1925 then in detail in 1926 (TAMURA 1925, 1926). The reports on the national parks were printed by the Sanitary Bureau in 1927 and 1930 (TAmura 1927, 1930). This double contract meant two things. First, the Forestry Agency had a certain interest in recreational development in their national forests at this stage. Second, TAMURA had not decided which agency was more suitable to manage the national parks before his departure to the United States. After his trip, however, the reports suggest he tended to favor park management by the Ministry of Home Affairs, mainly because the national park lands were not limited to national forests. He did not mention any other reasons. However, his preference for the Ministry of Home Affairs was presumably influenced by his meeting with Arthur CARHART in Denver in August, 1923. CARHART was employed as the first recreation engineer in the U.S. Forest Service in 1919, but quitted at the end of 1922, frustrated by the lack of understanding of recreational development by the foresters in the Forest Service (ITO, 1992).

\section{THE THIRD STAGE: ENACTMENT OF NATIONAL PARK LAW}

The third stage began when water development plans in several proposed areas were disclosed around 1927.
These proposals made the park promoters realize the urgency of the park establishment. The same year the national newspaper Mainichi held a campaign to identify "The Eight Most Outstanding Landscapes of Japan". This campaign clearly promoted public awareness of the national parks. The campaign asked the public to choose the best landscapes from eight categories such as mountains and lakes on 9 April 1932. This was similar landscape classification method to the one Tamura was employing to select proposed national park areas. Actually he became a member of the campaign selection committee and manipulated the result to include some proposed national park sites like Kamikochi ( TANAKA 1981, InUMA et al. 1993). The campaign provoked a national fever and attracted more than 93.4 million postcards in just one month (OsaKa Mainichi Shinbunsha 1927). It effectively accelerated the national park movement. Taking advantage of the increasing interest in landscapes among Japanese, in December of the same year, the National Parks Association was organized by influential politicians and businessmen to further promote national parks (National Park Association 1951).

Following these successes, establishment of a National Park Study Committee was declared at a cabinet meeting on 14 January 1930. The Committee was located in the Ministry of Home Affairs because the Minister ADACHI, whom TAMURA and other national park promoters had consulted, became interested in adding national parks to his Ministry, which had been responsible for city park management since 1873. However, the cabinet considered support from other agencies to be necessary, and the Committee had thirty-five members from various interests, including forestry specialists like Tomoaki HIRAKUMA, the Director of the Forestry Bureau and Suzuo TAKEI, the Chief of the Operations Department of the same Bureau.

The first Committee meeting was held on 11 July 1930. The Committee organized two subcommittees for detailed investigation and drafting of possible legal structure and selection guidelines. The first subcommittee prepared a draft national park bill. Its members studied foreign models, especially those of the United States and Italy, as well as various domestic laws. The draft bill proposed that parks be created by designating specific areas, including private lands, and that land-use be controlled by zoning with Ordinary and Special Areas within the park. The idea of designating parks over non-governmental lands was borrowed from the Italian national park system. The idea of regulatory zoning came from the Forest Law of 1897 , the City Planning Law of 1911, and the Historic Sites, Scenic Beauty and Natural Monument Preservation Law of 1911 (The Sanitary Bureau 1931a). The Forest Law had regulations on Protection Forests for various environmental effects, while the City Planning Law stipulated the designation of Scenic Districts to protect 
amenity in good residential areas.

The second Committee meeting was opened 31 October 1930 and a draft park bill prepared by the structural subcommittee was discussed (THE NATIONAL PARKS STUdY CommitTeE 1930). Questions regarding the draft bill were focused on the harvesting restriction of forested areas, which covered about $90 \%$ of park lands. In Special Areas, the private landowners had to obtain permission for harvesting and other land-use changes, according to the draft. If the private landowners suffered any economic loss because permission was rejected, the government had to compensate according to Article 9 of the draft bill. To simplify the permission process, it was proposed that the national forest management plan be adjusted in advance with the Forestry Bureau. The same procedure was extended to the private forests. Thus, even in private forests permission was not necessary if the owner had a forest management plan agreed to in advance. It became clear that a suitable forest management plan could substitute for the procedure stipulated in Article 8 of the bill, even in forests designated as Special Areas. A member of the subcommittee, AkAGI, mentioned that the regulation may prevent the interruption of harvesting in private forests designated as Special Areas and would avoid the compensation issue. This comment reflects the dilemma of the compensation article, which stipulates compensation against economic loss without budget allocation (SEINO 1993). It was a time of world depression and the budget was extremely tight.

During the same session, another subcommittee member, OKA, expressed an opinion favoring national park management by the Forestry Bureau for several reasons. First, the majority of national park lands belonged to national forests; especially seven of the proposed areas which were almost entirely national forests. Second, park management by an existing organization was more economical and the Forestry Bureau already had 193 offices, 1,500 workers and an annual revenue of 3.7 million yen. Third, the Bureau had field specialists including foresters and forest engineers to manage the national forests according to the Forest Law. However, this opinion was not expressed by the Forestry Bureau directly. The chief of the Bureau was a member of the National Park Study Committee and he had the chance to express any opinion on park management if he wished. As already mentioned, the Forestry Bureau had some interest in managing recreation in the 1920s. His silent response to OKA's opinion suggests that park management by the Ministry of Home Affairs was already settled by that time. TezukA (1984) explains that this inconsistency was a result of prior political agreement between the Ministers of Home Affairs and Agriculture and Forestry. This also explains why this committee was organized by the Ministry of Home Affairs with the clear objective of bringing the national park system under its control.
TAMURA knew that national parks in Italy were partially managed by the Forestry Bureau. Therefore, he was aware of the possibility of park management by the Forestry Bureau. However, he also learned that several new national parks were being created from national forests in the United States when he visited. Therefore, he stated in his report that national parks of Japan had to cover various lands and that independent national park management organization would be preferable (TAMURA, 1925). Reflecting his endorsement, a member mentioned that not all the park lands belong to the national forest, and national park management by the Ministry of Home Affairs was justified.

The National Park Law was passed on 1 April 1931. On 29 September of the same year, the third and last National Park Study Committee was held. The members ratified the selection guidelines in the report from the subcommittee (The National PARK Study Committee 1931a). The primary principle of national park selection was to preserve the outstanding sceneries of which Japan is so proud. Three specific selection guidelines were mentioned as follows.

1. The best one in each landscape category

2. Large-scale natural scenery

3. Outstanding geological features and landscape variation These reflect the monumentalism and nationalism found in early national parks petitions. As secondary guidelines, the following six factors were mentioned.

1. Capacity to accept mass-recreational use

2.Abundance of cultural resources such as temples and historic sites

3. Maximum use of public landownership

4. Geographic distribution convenient to the public

5. Little influence over industries

6. Existing facilities and future prospective to new ones.

\section{THE FOURTH STAGE: BOUNDARY DETERMINATION AND ZONING REGULATION}

The fourth stage began when the National Park Law was enforced and the new National Park Committee was organized on 1 October 1931. The mandate given to this new Committee was the selection and designation of specific areas as national parks.

The first meeting was held on 24 November 1931, and the chairman reported the selection guidelines already approved by the former National Park Study Committee (The National Park Committee 1931b). These guidelines were adopted by the new Committee without objection. Then, TAmuRA described in detail the fourteen areas which had been proposed on the basis of the guidelines. In addition to these, Daisetsuzan was recommended as a promising area. Expecting difficulty for choosing the most 
suitable areas from these proposals, the chairman organized a subcommittee for the site selection. TAMURA and HiRAKUMA were included in the eleven members.

During the session, a document titled Data of National Parks (The Sanitary Bureau 1931b) was supplied to the members. There were fourteen categories of information in this document. TAMURA explained that the first seven categories were related to the primary requirements of the selection guidelines. The first three were tables on landownership, private lands and national forests in each proposed area. The table on private lands ranked the fourteen areas by the ratio of private land; the smaller the ratio, the higher the priority. The table on national forest includes a similar ranking based on ratio but in the opposite order; the bigger the ratio, the higher the priority. This table also included forest management categories such as ordinary or restricted (Table 2). The forests without any cutting regulations were classified as ordinary. Forests already classified as Protection Forests or Preservation Forests were recognized as restricted or semirestricted depending on the degree of restriction. From these tables it became evident that land ownership was the key factor of various conditions. The role of national forests was especially recognized, and the forestry practice restrictions were seriously investigated.

By the second meeting of the National Parks Committee, the subcommittee on site selection had made several field investigations and held sixteen meetings with heated discussions to choose the most suitable areas from the fifteen proposed areas. During the year-long process, the contents of the areas were modified from the original survey report (Table 3 ). Most notably, private areas were drastically reduced. Finally, twelve national park areas were selected, and Noboribetsu-Shikotsu, Onuma and Bandai-Azuma were omitted. This result was reported to the second Committee meeting held on 8 October 1932 (THE National Park CommitTee 1932), but the reasons for the exclusion of these three areas were not mentioned.

The second Committee meeting approved the twelve areas as national parks, although the boundaries were not determined yet. The boundary issues were closely related to industrial use and local interests. The Committee organized a special subcommittee on boundaries to discuss the matter in detail by the next meeting.

To decide the national park boundaries, the forestry regulations in the parks were discussed with the Forestry Bureau. As noted above, certain forests in Japan were already under some protection, and Directive No. 30 of the Ministry of Agriculture and Forestry in 1907 originally specified fundamental forest practice rules such as cutting methods and size (The Forestry Bureau 1940). As the TAMURA Library contains several underlined papers on the Protection Forests and their treatment methods, he was sure to have consulted these rules before defining the forest landscape management guidelines for national parks.

On 25 September 1933, the Forestry Bureau asked about the detailed restriction of forestry in Unzen and Setonaikai national parks. On 6 October, the Ministry of

Table 2 Status of Imperial and National Forests in the Proposed National Park Areas (November 1931)

\begin{tabular}{|c|c|c|c|c|c|c|c|c|c|c|c|c|}
\hline \multirow[t]{2}{*}{ Number } & \multirow[t]{2}{*}{ Name } & \multirow{2}{*}{$\begin{array}{l}\text { Park Area } \\
\text { (ha) }\end{array}$} & \multirow{2}{*}{$\begin{array}{c}\text { Imp. \& Nat. } \\
\text { Forests } \\
\text { (ha) }\end{array}$} & \multirow{2}{*}{$\begin{array}{l}\text { Ratio of } \\
\text { Imp. \& Nat. } \\
\text { Forests } \\
(\%)\end{array}$} & \multicolumn{8}{|c|}{$\begin{array}{c}\text { Forestry Practice Categories and the Ratios in the Imp. \& Nat. } \\
\text { Forests }\end{array}$} \\
\hline & & & & & Ordinary & $(\%)$ & Semi-restri & icted (\%) & Restricted & $d(\%)$ & Left-over & $(\%)$ \\
\hline 1 & Akan & 76,100 & 50,846 & 66.8 & 24,439 & 48.1 & 0 & 0 & 23,963 & 47.1 & 2,444 & 4.8 \\
\hline 2 & Noboribetsu & 6,500 & 4,926 & 75.8 & 504 & 10.2 & 0 & 0 & 4,337 & 88 & 85 & 1.7 \\
\hline 3 & Onuma & 19,400 & 6,346 & & 0 & 0 & 6,346 & 100 & 0 & . & 0 & 0 \\
\hline 4 & Towada & 50,300 & 43,810 & .1 & 16,118 & 36.8 & 18,110 & 41.3 & 2,962 & 6.8 & 6,620 & 15.1 \\
\hline 5 & Bandai-Azuma & 65,000 & 33,415 & & 20,173 & 60.4 & 1,771 & 5.3 & 10,045 & 30.1 & 1,426 & 4.3 \\
\hline 6 & Nikko & 53,5 & 31,9 & & 7,630 & 23.9 & 3,566 & 11.2 & 17,980 & 56.2 & 2,798 & 8.8 \\
\hline 7 & Fuji* & 86,800 & 25,592 & 29.5 & 7,859 & 30.7 & 0 & 0 & 2,587 & 10.1 & 3,575 & 14 \\
\hline 8 & Nihon Alps & 174,600 & 150,918 & & 30,366 & 20.1 & 30,777 & 20.4 & 50,372 & 33.4 & 39,403 & 26.1 \\
\hline 9 & Odaigahara-Ominesan & n 35,100 & 5,240 & 14.9 & 3,747 & 71.5 & 0 & 0 & 1,461 & 27.9 & 32 & 0.6 \\
\hline 10 & Daisen & 18,300 & 8,244 & 45.0 & 5,688 & 69 & 373 & 4.5 & 2,183 & 26.5 & 0 & 0 \\
\hline 11 & Setonaikai** & 2,400 & 481 & 20.0 & 0 & 0 & 0 & 0 & 450 & 93.6 & 31 & 6.4 \\
\hline 12 & Aso & 30,800 & 2,786 & 9.0 & 2,186 & 78.5 & 378 & 13.6 & 181 & 6.5 & 41 & 1.5 \\
\hline 13 & Unzen & 10,400 & 7,957 & 76.5 & 2,565 & 32.2 & 1,598 & 20.1 & 648 & 8.1 & 3,146 & 39.5 \\
\hline \multirow[t]{2}{*}{14} & Kirishima & 19,500 & 18,450 & 94.6 & 11,108 & 60.2 & 5,984 & 32.4 & 40 & 0.2 & 1,318 & 7.1 \\
\hline & Total & 648,700 & 390,985 & 60.3 & 132,383 & 33.9 & 68,903 & 17.6 & 117,209 & 30 & 60,919 & 15.6 \\
\hline
\end{tabular}

* Total area includes transferable lands of 11,571ha.

**Name was changed from Yashima-Shodoshima, and water surface was excluded from figures.

Source: The Sanitary Bureau (1931b) 
Table 3 Landownership of the Proposed National Park Areas (October 1932)

\begin{tabular}{|c|c|c|c|c|c|c|c|c|}
\hline Number & Name & $\begin{array}{l}\text { Park Area } \\
\text { (ha) }\end{array}$ & $\begin{array}{c}\text { Imperial } \\
\text { Lands (ha) }\end{array}$ & $\begin{array}{c}\text { National } \\
\text { Lands (ha) }\end{array}$ & $\begin{array}{c}\text { Public } \\
\text { Lands (ha) }\end{array}$ & $\begin{array}{l}\text { Religious } \\
\text { Lands (ha) }\end{array}$ & $\begin{array}{c}\text { Private } \\
\text { Lands (ha) }\end{array}$ & $\begin{array}{l}\text { Ratio of } \\
\text { Private } \\
\text { Lands }(\%)\end{array}$ \\
\hline 1 & Akan & 76,100 & 22,400 & 43,500 & 0 & 0 & 10,200 & 13.4 \\
\hline 2 & Daisetsuzan* & 204,700 & 26,400 & 172,900 & 5,400 & 0 & 0 & 0.0 \\
\hline 3 & Noboribetsu-Shikotsu** & 116,100 & 91,100 & 23,500 & 0 & 0 & 1,500 & 1.3 \\
\hline 4 & Onuma & 19,400 & 0 & 9,200 & 700 & 0 & 9,500 & 49.0 \\
\hline 5 & Towada & 50,300 & 0 & 49,200 & 0 & 0 & 1,100 & 2.2 \\
\hline 6 & Bandai-Azuma & 65,000 & 0 & 35,000 & 21,400 & 0 & 8,600 & 13.2 \\
\hline 7 & Nikko & 53,500 & 13,100 & 18,900 & 100 & 3,800 & 17,600 & 32.9 \\
\hline 8 & Fuji & 86,800 & 25,600 & 2,200 & 41,400 & 300 & 17,300 & 19.9 \\
\hline 9 & Nihon Alps & 174,600 & 5,800 & 145,200 & 16,100 & 0 & 7,500 & 4.3 \\
\hline 10 & Yoshino Mts. -Kumano*** & 52,300 & 5,900 & 800 & 10,300 & 100 & 35,200 & 67.3 \\
\hline 11 & Daisen & 18,300 & 0 & 8,200 & 8,100 & 0 & 2,000 & 10.9 \\
\hline 12 & Setonaikai & 2,400 & 0 & 800 & 400 & 100 & 1,100 & 45.8 \\
\hline 13 & Aso & 30,800 & 0 & 4,700 & 24,800 & 0 & 1,300 & 4.2 \\
\hline 14 & Unzen & 10,400 & 0 & 8,000 & 2,000 & 0 & 400 & 3.8 \\
\hline \multirow[t]{2}{*}{15} & Kirishima & 19,500 & 0 & 18,500 & 0 & 100 & 900 & 4.6 \\
\hline & Total & 980,200 & 190,300 & 540,600 & 130,700 & 4,400 & 114,200 & 11.7 \\
\hline
\end{tabular}

* New addition

** Name was changed from Noboribetsu, and the area was enlarged.

***Name was changed from Odaigahara-Ominesan.

Source: TAMURA (1932)

Home Affairs answered with a document describing the restrictions on forest management practice (THE PHYSICAL Strength Bureau 1940). The Forestry Bureau agreed to these restrictions on 20 October.

As shown in the following general principles, this document was virtually a landscape management guidelines which controlled all forests in national parks. Its general principles were as follows.

1. The maximum clear-cut area is determined by dividing the forest area with cutting period.

2. The allowed select-cut area is equivalent to the annual growth rate or $2 \%$ of the growing stock for natural forests.

3. If not harvested annually, the cut area can be enlarged by multiplying the allowed annual cut-area by the interval without cutting.

4.Clear-cut areas should be restocked within three years of harvesting.

5. Trees to be protected for esthetic reasons can be designated by the Ministry.

6. Areas for planting and the species composition can be designated by the Ministry.

In Special Areas, more detailed restrictions were made as follows:

1. Natural forests should be naturally regenerated.

2. Minimum harvesting ages are twenty years for small species and sixty years for tall species.

3. Maximum clear-cut size is $0.5 \mathrm{ha}$, but it can be enlarged if there are leftover trees.

4. There should be a five to ten-year interval between clear -cutting adjoining areas. This can be shortened if landscape damage is not expected.

5. Maximum select-cut volume is one third of the growing stock, or one half in the case of evergreen species.

6 . The species and forest types can be changed if they are manmade forests.

7. Harvesting methods can be specified for landscape management.

8. Special consideration can be given to private forests.

Ordinary Areas had less-tight regulations as follows:

1. Natural forests should be naturally regenerated if possible.

2. Maximum clear-cut size is $10 \mathrm{ha}$, but can be enlarged if there are leftover trees.

3 . The species and forest type can be changed in case of manmade regeneration.

4. Harvesting methods can be specified for landscape management.

5. Special consideration can be given to the private forests.

These guidelines became less restrictive than the original draft plan, presumably as a result of various compromises. For example, clear-cut size was enlarged from 5ha to 10 ha in Ordinary Areas. Nevertheless, the guidelines were much stricter than those that applied at this time.

In addition to these guidelines, the National Park 
Table 4 Landownership of the Designated National Park Areas(1938)

\begin{tabular}{rlrrrrrrr}
\hline \multirow{2}{*}{ Number } & \multicolumn{1}{c}{$\begin{array}{c}\text { Park Area } \\
\text { (ha) }\end{array}$} & $\begin{array}{c}\text { Imperial } \\
\text { Lands(ha) }\end{array}$ & $\begin{array}{c}\text { National } \\
\text { Lands(ha) }\end{array}$ & $\begin{array}{c}\text { Public } \\
\text { Lands(ha) }\end{array}$ & $\begin{array}{c}\text { Religious } \\
\text { Lands(ha) }\end{array}$ & $\begin{array}{c}\text { Private } \\
\text { Lands(ha) }\end{array}$ & $\begin{array}{c}\text { Ratio of } \\
\text { Private } \\
\text { Lands(\%) }\end{array}$ \\
\hline 1 & Akan & 87,498 & 27,263 & 47,591 & 170 & 0 & 12,474 & 14.3 \\
2 & Daisetsuzan & 231,929 & 25,146 & 199,648 & 7,135 & 0 & 0 & 0.0 \\
3 & Towada & 42,862 & 0 & 41,722 & 830 & 0 & 310 & 0.7 \\
4 & Nikko & 56,923 & 12,976 & 19,865 & 816 & 466 & 22,800 & 40.1 \\
5 & Fuji-Hakone* & 71,757 & 15,371 & 3,124 & 34,624 & 426 & 18,212 & 25.4 \\
6 & Chubu Sangaku** & 169,768 & 3,667 & 144,221 & 12,870 & 0 & 9,010 & 5.3 \\
7 & Yoshino-Kumano & 55,086 & 5,094 & 3,443 & 11,804 & 272 & 34,473 & 62.6 \\
8 & Daisen & 12,403 & 0 & 6,052 & 5,558 & 83 & 710 & 5.7 \\
9 & Setonaikai*** & 183,100 & 0 & 173,363 & 1,437 & 300 & 8,000 & 4.4 \\
10 & Aso & 67,827 & 0 & 8,943 & 36,271 & 36 & 22,577 & 33.3 \\
11 & Unzen & 13,029 & 0 & 8,077 & 2,042 & 30 & 2,880 & 22.1 \\
12 & Kirishima & 21,560 & 0 & 20,177 & 217 & 7 & 1,159 & 5.4 \\
\hline
\end{tabular}

* Name was changed from Fuji.

** Name was changed from Nihon Alps.

${ }^{* * *}$ Area includes water surface as national land.

Source: THE Ministry OF Welfare (1948) (obvious mistakes corrected and format adjusted)

圆布分图公立图

MAP SHOWING THE DISTRIBUTION OF NATIONAL PARKS

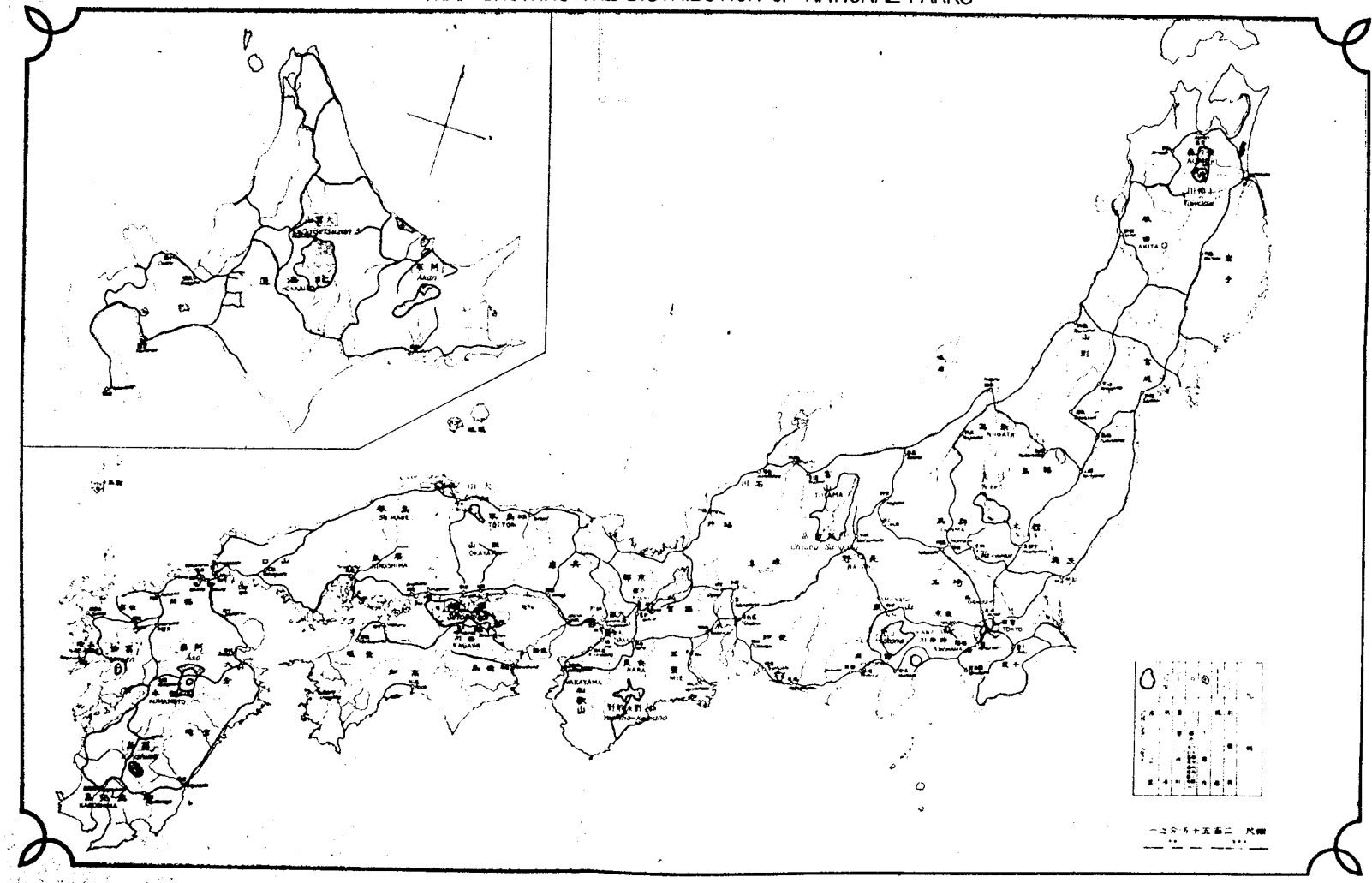

Fig. 2 Map of Original Twelve National Parks (Amishima 1938) 
Planning Guidelines was established by the Ministry of Home Affairs in 1937. They say that if possible private lands should not be designated as Special Areas, and that boundaries should follow the management lines of national forests. Another interesting specification is for Special Areas along road sides. It says the width of the belt should be $100 \mathrm{~m}$ each side of the center of the road. Such an idea must have come from the national forest management rules, which were intended to shield ugly forestry practices such as clear cutting from the road.

During the time when the forest landscape management guidelines in the parks were discussed, several articles on forestry practice in the national parks appeared. Most of them expected that the economic loss incurred by regulation would be small if select cutting was allowed, and that the benefits from accelerated road construction in the parks could exceed such loss (FuJISHIMA 1932, KuRATA 1934, TomiYa 1934). However, Nagata pointed out the greater risk of fire hazards and the resulting rise of insurance fee (NAGATA 1934). Reflecting this view, Shioya urged allocation of sufficient budget funds to compensate private forest owners in Special Areas (SHIOYA, 1937).

After establishing the forest landscape management guidelines, boundaries of the three first-stage national parks, namely Setonaikai, Unzen, Kirishima were decided in the fourth Committee meeting on 19 December 1933, and officially designated on 16 March the following year. The fifth Committee meeting chose five second-stage parks; Akan, Daisetsuzan, Nikko, Chubu Sangaku (formerly Nihon Alps) and Aso on 9 August 1934. These parks were designated on 4 December of the same year. The decision of the final four parks was delayed until 15 January 1936 because of complicated private lands issues and the adjustment of industrial uses. For example, more than $60 \%$ of Yoshino was private land used mainly for timber production. Finally those parks were designated on February 1, 1936 , and a system of twelve parks was established.

The Table 4 shows the land ownership of the twelve national parks. Comparisons with Table 1 clarify the increased portion of national land and the according decrease of private land to $13 \%$. This was a direct result of the efforts to eliminate private lands in each park. The trend was clearly accelerated by the inclusion of Daisetsuzan in 1931, which is the largest park without private lands. As shown in the map (Fig. 2) included in an early guide book (AMISHIMA 1938), these parks seem evenly distributed over Japan and reflect a consideration of access factors.

\section{DISCUSSION}

The role of private land, especially with respect to their forest management, was a critical factor in the formation of the national park policy in Japan. To cope with this issue, national forests areas were preferred as core areas, then regulation in private forests was seriously considered. This approach was due to the following three factors.

First of all, forest was the predominant landscape in Japan, and forestry was a major industry in such areas. However, the economic demands for resources in isolated areas were weak due to the difficulty of transporting logs over steep topography. Such areas were often designated as national forests. There were some private lands even in isolated scenic areas, but forestry was small scale and machines were not introduced yet. Therefore, the humaninfluenced landscape was compatible with the natural one in those days, and such human influence was recognized as a positive factor which enhanced the landscape. For this reason, cultural and historic factors were included as the secondary selection requirement when the national park selection guidelines were formulated. In other words, park planners did not consider just natural landscapes.

Second, not only national parks but also national park promoters were strongly tied to forestry. Many articles related to national parks were published in the forestry magazines. Furthermore, the national park promoters like TAMURA and his advisor S. HondA were major forestry specialists of the age. They were influential in the Forestry Bureau because they were authorities in both forestry and landscape architecture, and because their colleagues were working there.

In those days, the sustainable forestry idea from Germany was popular among foresters (YAMAHATA 1984). The sustainable management theory published by A. MöEL LER in 1922 was translated to Japanese in 1927. The forest esthetics concept of $\mathrm{H}$. von SALISCH was also introduced to Japan in 1910. Under these influences, the first Japanese book on forest esthetics was published in 1918 (NIJIMA and Murayama 1918). TAMURA also published several papers and a book on this topic (TAMURA 1929a). Thus, foresters were familiar with the roles of forests other than timber production, and were receptive to timber cut regulations. That explains the favorable attitudes of foresters to the restriction of forestry in national parks.

Third, there were some overseas precedents and domestic laws which the park promoters could consult as models. These models gave the national parks of Japan their start as a system. Of the overseas examples, American national parks and their cultural resources were influential. TAMURA intentionally introduced the concept of small American national parks like Hot Springs before introducing large and ideal parks like Yellowstone in his magazine articles (TAMURA 1929b). This reflects his idea that these small parks on private land could be better models for Japan. He also studied the relation between the National Park Service and the Forest Service in the United States carefully and decided that park management in Japan should be the responsibility of the Ministry of Home 
Affairs.

Among the existing laws consulted during the drafting of the National Park Law, the Protection Forest system of the Forest Law and Preserved Forest by regulation of the Forestry Bureau were of great help in developing the park idea and identifying potential areas. Although the Historic Sites, Scenic Beauty and Natural Monument Preservation Law of 1911, prohibited any timber production from forests designated as Natural Monuments, the Protection Forests system allowed a specified amount of timber to be cut, and provided for compensation. The Protection Forests system as an important precedent to the National Parks Law, and many of these areas were included in the parks later.

\section{CONCLUSION}

Regulatory zoning was the essence of Japan's national park policy, and was far ahead of its time. The Special and Ordinary areas of the early national park policy are equivalent to the recent core-buffer zone concept which features in international discourse on conservation. The regulatory zoning system was included by the Sanitary Bureau as a management guideline for national forest lands within national parks. Nevertheless, TANAKA (1981) noted that the significance of the zoning regulation in the national park system was not recognized by the park planners at that time. He mentioned three reasons for this lack of recognition. First, Japanese have traditionally accepted mixtures of living space and scenic public space. Second, the proposed areas were isolated and undeveloped except for Yoshino area. Third, the proprietary rights of local farmers and mountain villagers had been ignored from feudal days, and the Ministry of Home Affairs was the center of political power in the government before the Second World War.

If such social factors are considered, the national park system based on zoning regulation was the most suitable choice for Japan in those days. However, social factors such as demand for timber and land ownership rights changed radically after the Second World War. The demand for timber in remote national forests surged, and restriction of timber harvest in private forests became more difficult. This trend was further accelerated by a power shift in the bureaucracy. While park management responsibility was transferred from the Ministry of Home Affairs to the Ministry of Welfare in 1938, then to the Environment Bureau in 1972, the national forests were put under a special self-supporting account of the Forestry Bureau in 1947.

Though the forest landscape management guidelines were an excellent way to control landscapes in the parks systematically, this remained one of the fragile rules in the government. The guidelines could be modified without public notice, and secretly changed. Indeed, these regulations were diluted as the authority of the national parks management was weakened and economic considerations became more important in the management of national forests. For instance, the maximum clear-cut allowance in the Special Areas doubled to 1ha in 1950, then to 2 ha in 1959. This trend which lowered the quality of park landscapes was not stopped even the passing of the Natural Park Law in 1957. To improve landscape quality, a program to purchase private lands in Special Areas was introduced in 1972. However, the budget has always remained nominal. The double agency management and the forest landscape management guidelines were the brainchildren of the national park planners in Japan, and fitted the social conditions in those days. However, it is getting difficult to adjust park management to modern social conditions.

This stady was partially supported by Grant-in-Aid for Scientific Research $(\mathrm{C})$ from Japanese Ministry of Education, Science and Culture.

\section{LITERATURE CITED}

Amishima, J. (ed.), (1938): The National Parks of Japan. Asahikawa Shinbunsha, 132pp originally published in 1933 (Japanese with English summary)

The Forestry Bureau, (1940): The outline of laws related to the Forest Law. Kasumigaseki Shobo (in Japanese)

Fuishima, S., (1932): Influence of forestry practice restriction in National Parks over forest economy. Kokuritsu Koen 4(1): 18-20 (in Japanese)

Iinuma, J. and Shirahata, Y., (1993): Public Parks as Japanese culture. Yasaka Shobo, 228pp (in Japanese)

ITo, T., (1992) Development of recreation in the U.S. National Forests. Bull. of the Kyoto Univ. For. 64:141-155 (in Japanese with English summary)

Kurata, Y., (1934): An observation on forest management in National Parks. Kokuritsu Koen 6 (8): 2-7 (in Japanese)

The Ministry of Welfare, (1948): Laws related to the National Park, 128pp (in Japanese)

Nagata, R., (1936): The relation between National Parks and private forests. Sanrin 641: 2-11 (in Japanese)

The National Park Association, (1951): Outline of the National Park Association. (in Japanese)

The National Park Study Commitree, (1930): Proceedings of the second National Park study commission held on Oct. 31, 1930. 42pp (in Japanese)

The National Park Study Committee, (1931a): Proceedings of the third National Park Study Commission held on Sep. 29, 1931. 21pp (in Japanese)

The National Park Committee, (1931b): Proceedings of the first National Park Commission held on Nov. 24, 1931. 36pp (in Japanese)

The National Park Committee, (1932): Proceedings of the second 
National Park Commission held on Oct. 8, 1932. 26pp (in Japanese) Ninjima, Y. and Murayama, J., (1918): Forest esthetics, Seibido, 680pp (in Japanese)

Osaka Mainichi Shinbunsha, (1927): The eight most outstanding landscapes of Japan. 32 Plates.

The Physical Strength Bureau, The Ministry of Health and Wel. FARE, (1940): Laws and rules related to National Parks. (in Japanese)

Runte, A., (1979): National Parks- The American experience. Univ. of Nebraska Press, 239pp

The Sanitary Bureau and The Ministry of Home Affairs, (1930a): Outline of National Parks proposed areas. the Ministry of Home Affairs, 81pp (in Japanese)

The Sanitary Bureau and The Ministry of Home Affairs, (1930b): Maps of National Parks proposed areas. the Ministry of Home Affairs, 14 maps (in Japanese)

The Sanitary Bureau and The Ministry of Home Affairs, (1931a): Conferred laws for the National Parks Law. unpublished paper found in the TAMURA Library (in Japanese)

The Sanitary Bureau and The Ministry of Home Affairs, (1931b): The data of National Parks. (in Japanese).

The Sanitary Bureau and The Ministry of Home Affairs, (1932a): Outline of proposed National Park areas supplement 1. the Ministry of Home Affairs, 5pp (in Japanese)

The Sanitary Bureau and The Ministry of Home Affairs, (1932b): Outline of proposed National Park areas supplement 2. the Ministry of Home Affairs, 13pp (in Japanese)

SEINO, T., (1994): Development of National Park system. unpublished master's thesis. 51 pp (in Japanese)

Shloya, T., (1937): Contacts between National Parks and forestry. Kokuritsu Koen 9(11): 17-20 (in Japanese)

SugiurA, K., (1971): Natural Parks and forests. Kokuritsu Koen 265:9
-13 (in Japanese)

Tamura, T., (1925): Forest recreation facilities in the United States and the conditions in Japan. Sanrin 513: 23-31 (in Japanese)

TAmura, T., (1926): Outline of recreation facilities in the United States and Canada. The Forestry Bureau, 68pp (in Japanese)

Tamura, T., (1927): National Parks. the Sanitary Bureau the Ministry of Home Affairs, 54pp ( in Japanese)

TAMURA, T., (1929a): Forest landscape planning. Seibido, 230pp (in Japanese)

Tamura, T.,(1929b): Hot springs National Park. Kokuritsu Koen 1 (4): 8-10 (in Japanese)

TAmura, T., (1930): National Parks abroad. the Sanitary Bureau, the Ministry of Home Affairs, 121pp (in Japanese)

TAmura, T., (1932):Documents on National Park selection. unpublished paper found in the Tamura library (in japanese)

Tamura, T., (1948): National Parks lectures. Meiji Shoin, 291pp (in Japanese)

Tamura, T., (1951): National Parks of Japan. National Parks Association, $291 \mathrm{pp}$ (in Japanese)

TAnaka, M., (1981): National Parks of Japan. Sagami Shobo, 284pp (in Japanese)

TEzUKA, H.,(1984): The road forests followed. Nippon Ringyo Gijutsu Kyokai, 347 pp (in Japanese)

Tomrya, M.,(1934): Private virgin forest owners should not worry about National Park designation. Kokuritsu Koen 6(6): 4-7 (in Japanese)

YamanatA, K., (1984): The idea of sustainable forests. Toshi Bunkasha, 211pp (Japanese translation of Moeller's book published in 1922)

(Received 13 June 1996)

(Accepted 3 August 1996) 